\title{
Gambaran Keton Urin pada Primigravida Trimester 1 dengan Hiperemesis Gravidarum di RS Islam Sitti Maryam Manado
}

\author{
${ }^{1}$ Nunung Karmila \\ ${ }^{2}$ Arthur E. Mongan \\ ${ }^{2}$ Glady I. Rambert
}
${ }^{1}$ Program Studi Pendidikan Dokter Fakultas Kedokteran Universitas Sam Ratulangi Manado
${ }^{2}$ Bagian Ilmu Patologi Klinik Fakultas Kedokteran Universitas Sam Ratulangi Manado Email: karmilanunung99@gmail.com

\begin{abstract}
Hyperemesis gravidarum could cause weight loss of more than 5\%, dehydration, and electrolyte loss. In this condition the body will metabolize fat, therefore, there is an increase in ketone level in the blood (ketosis) which can deplete the body's base reserve and cause acidosis as well as ketones in the urine (ketonuria). In some cases it can cause fetal death or even the mother. This study was aimed to obtain the description of urinary ketone in primigravids in first trimester with hyperemesis gravidarum in Manado. This was an observational descriptive study with a cross sectional design. Urine samples were taken by using non-probability sampling with consecutive sampling. The results showed 10 primigravids in first trimester with hyperemesis treated at Sitti Maryam Islamic Hospital Manado during November-December 2018. Based on the laboratory tests performed on all subjects, there were 3 primigravids (30\%) who had ketonuria. Conclusion: Some primigravids in first trimester with hyperemesis gravidarum had ketonuria.
\end{abstract}

Keywords: primigravids, first trimester, hyperemesis, ketonuria

\begin{abstract}
Abstrak: Pada hiperemesis gravidarum dapat terjadi penurunan berat badan hingga lebih dari $5 \%$, dehidrasi, dan kehilangan elektrolit. Pada keadaan ini tubuh akan memetabolisme lemak sehingga terjadi peningkatan kadar keton dalam darah (ketosis) yang dapat menghabiskan cadangan basa tubuh dan menyebabkan asidosis serta terdapatnya keton dalam urin (ketonuria). Pada beberapa kasus dapat terjadi kematian janin maupun ibu. Penelitian ini bertujuan untuk mengetahui gambaran keton urin pada primigravida trimester I dengan hiperemesis gravidarum di Kota Manado. Jenis penelitian ialah deskriptif observasional dengan desain potong lintang. Sampel urin diambil dengan cara non-probability sampling jenis consecutive sampling. Hasil penelitian mendapatkan subyek penelitian yang terdiri dari 10 primigravida trimester 1 dengan hiperemesis yang dirawat di RS Islam Sitti Maryam Manado selama bulan November-Desember 2018. Berdasarkan hasil pemeriksaan laboratorium dari 10 subyek (100\%) terdapat 3 primigravida (30\%) yang mengalami ketonuria. Simpulan: Sebagian primigravida trimester I dengan hiperemesis gravidarum mengalami ketonuria.
\end{abstract}

Kata kunci: primigravida, trimester 1, hiperemesis, ketonuria

Menurut Federasi Obstetri Ginekologi Internasional, kehamilan diartikan sebagai fertilisasi atau penyatuan dari spermatozoa dan ovum yang kemudian dilanjutkan dengan nidasi dan inplantasi. Kehamilan normal dimulai dari fase fertilisasi hingga bayi dilahirkan berlangsung sekitar 40 minggu atau 10 bulan lunar atau sekitar 9 bulan 7 hari menurut kalender internasioanal. Primigravida adalah wanita yang 
hamil untuk pertama kalinya sedangkan multigravida adalah seorang wanita yang hamil beberapa kali. ${ }^{1}$ Waktu kehamilan dibagi dalam tiga trimester, yaitu: trimester satu, mulai dari awal fertilasi hingga minggu ke-12; trimester dua berlangsung selama 13 minggu (minggu ke-13 hingga ke-27); dan trimester ketiga berlangsung dari minggu ke-28 hingga ke-40. Kriteria kehamilan normal ialah ibu sehat, tidak ada riwayat kelainan obstetrik, ukuran uterus sesuai dengan usia kehamilan, pemeriksaan fisik dan laboratorium normal. ${ }^{2}$

Pada kehamilan perubahan anatomi dan fisiologi sebagian besar sudah terjadi segera setelah fertilisasi dan terus berlanjut selama kehamilan. Sejumlah perubahan metabolik dan fisik terjadi untuk mengoptimalkan kesehatan janin. Perubahan terjadi menyeluruh pada organ ibu hamil sesuai dengan usia kehamilan dalam trimester. ${ }^{3}$

Perubahan organ yang terjadi yaitu pada sistem reproduksi, payudara, kulit, sistem metabolik, osmoregulasi, hematologi, kardiovaskuler, pernafasan, urinaria dan sistem lainnya. ${ }^{2}$ Selama kehamilan beberapa gejala dapat terjadi antara lain adalah lemas, tidak mau makan, berat badan turun, rasa nyeri epigastrium, nadi 100x/menit, tekanan darah turun, lidah kering, mata cekung dan kejadian yang paling sering terjadi adalah mual muntah secara terus menerus. ${ }^{4}$ Keluhan mual dan muntah persisten yang merupakan gejala yang umum dan wajar terjadi pada usia kehamilan trimester I. Mual biasanya terjadi pada pagi hari (morning sickness), akan tetapi dapat juga timbul setiap saat dan pada malam hari. Mual dan muntah terjadi pada $60-80 \%$ primigravida dan $40-$ $60 \%$ multigravida. ${ }^{5}$ Bila mual muntah semakin berat dan tidak tertanggulangi maka disebut hiperemesis gravidarum.

Pada trimester 1, sekitar $80 \%$ mengalami hiperemesis garvidarum. Menurut World Health Organization (WHO) jumlah kejadian hiperemesis gravidarum mencapai $12,5 \%$ dari jumlah seluruh kehamilan di dunia. Dari survei awal yang dilakukan peneliti di Rumah Sakit Umum Daerah Dr. Sam Ratulangi Tondano Kabupaten Mina- hasa Provinsi Sulawesi Utara, jumlah ibu hamil untuk Januari 2012 s/d 5 Februari 2013 yaitu 2060 orang, dan terdapat 116 (6\%) ibu hamil yang mengalami emesis gravidarum terbanyak pada primigravida yaitu 73 orang $(63 \%)$ dan sebagian besar berusia $\leq 20$ tahun. Yang mengalami hiperemesis gravidarum ialah $74 \mathrm{ibu}(3 \%)$ terbanyak pada primigravida yaitu 45 orang $(60 \%)$ dan sebagian besar berusia $\leq 20$ tahun.

Hiperemesis gravidarum ditandai dengan mual, muntah, susah makan dan rasa lemah pada badan. Hal ini mengganggu metabolisme tubuh dan menyebabkan komplikasi serta dehidrasi, hipokalemi, penurunan berat badan dan ketonuria. ${ }^{6}$ Pada kehamilan, hiperemesis gravidarum merupakan mual muntah yang berlebihan sehingga akan menyebabkan penurunan berat badan hingga lebih dari 5\%, dehidrasi dan kehilangan elektrolit. Pada keadaan ini tubuh akan memetabolisme lemak sehingga terjadi peningkatan kadar keton dalam darah (ketosis) yang dapat menghabiskan cadangan basa tubuh dan menyebabkan asidosis serta keton dalam urin (ketonuria). ${ }^{7}$ Pada beberapa kasus dapat menyebabkan kematian janin atau bahkan kematian ibu; oleh sebab itu diperlukannya pemeriksaan ketonuria untuk mendeteksi adanya keton dalam urin sehingga wanita hamil dapat mengontrol nutrisi agar tidak terjadi gangguan pada janin maupun pada ibu sendiri.

Penelitian ini bertujuan untuk mengetahui gambaran keton pada primigravida trimester I dengan hiperemesis gravidarum di Rumah Sakit Sitti Maryam. Penelitian ini seharusnya dilakukan di Rumah Sakit tipe C di Kota Manado namun karena beberapa rumah sakit sedang melakukan proses akreditasi maka penelitian hanya dilakukan di RS Islam Sitti Maryam Manado.

\section{METODE PENELITIAN}

Penelitian ini merupakan studi deskriptif observasional dengan desain potong lintang. Penelitian dilakukan di RS Islam Sitti Maryam Manado. Pemeriksaan sampel 
urin dilakukan di Laboratorium Pro-Kita. Waktu penelitian dilakukan pada bulan Oktober-November 2018. Subyek penelitian ialah primigravida trimester I dengan hiperemesis gravidarum di RS Islam Sitti Maryam Manado. Sampel penelitian ialah sampel urin sewaktu dari 10 primigravida trimester I dengan hiperemesis gravidarum yang memenuhi kriteria inklusi. Sampel diambil dengan cara non-probability sampling jenis consecutive sampling untuk mendapatkan urin dari semua primigravida trimester I dengan hiperemesis gravidarum dalam waktu dan kriteria yang telah ditentukan. Data yang diperoleh dikumpulkan, diolah (dalam bentuk tabel), dan disusun secara komputerisasi menggunakan program Microsoft Excel.

\section{HASIL PENELITIAN}

Penelitian ini dilakukan di Rumah Sakit Islam Sitti Maryam Manado terhadap 10 orang wanita hamil trimester 1 dengan hiperemesis gravidarum yang rawat inap di rumah sakit tersebut selama bulan November - Desember 2018. Pemeriksaan sampel urin dilakukan di Laboratorium Pro-Kita Manado.

Gambar 1 memperlihatkan berdasarkan kelompok usia subyek penelitian didapatkan terbanyak pada usia 18-23 tahun yakni sebanyak 6 orang $(60 \%)$ dan kelompok usia 24-29 tahun sebanyak 4 orang (40\%).

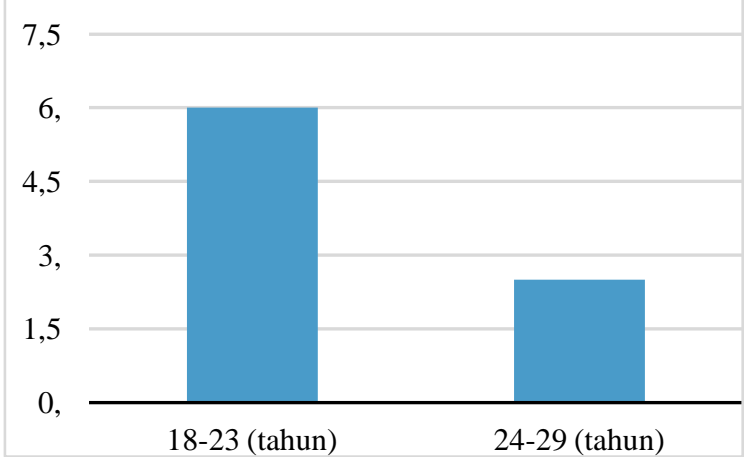

Gambar 1. Distribusi subyek penelitian berdasarkan usia

Gambar 2 memperlihatkan distribusi nilai keton pada wanita hamil terbanyak didapatkan dengan nilai negatif sebanyak 7 orang $(70 \%)$, positif dengan nilai $+(5$ $\mathrm{mg} / \mathrm{dL}$ ) sebanyak 2 orang $(20 \%)$, dan nilai +++ (50 mg/dL) sebanyak 1 orang $(10 \%)$.

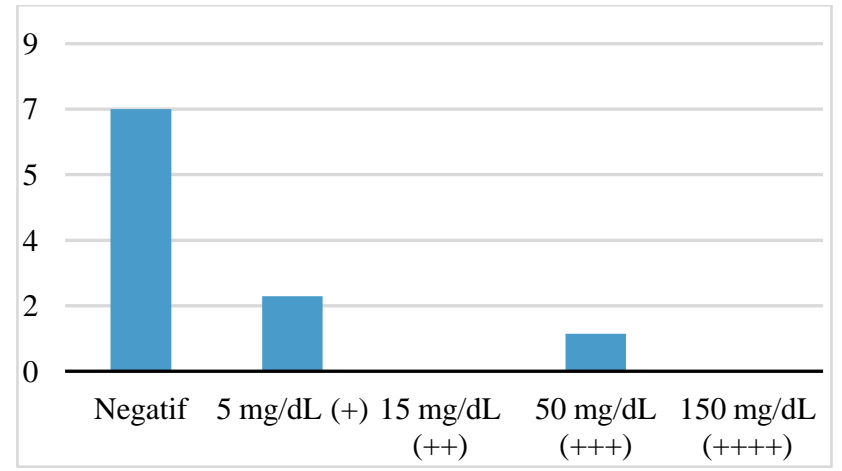

Gambar 2. Distribusi nilai keton

Tabel 1 memperlihatkan distribusi kadar keton urin berdasarkan kelompok usia. Pada kelompok usia 18-23 tahun didapatkan nilai keton negatif sebanyak 4 orang, positif dengan $+(5 \mathrm{mg} / \mathrm{dL})$ sebanyak 1 orang, dan $+++(50 \mathrm{mg} / \mathrm{dL})$ sebanyak 1 orang. Pada kelompok usia 24-29 tahun didapatkan nilai keton negatif sebanyak 3 orang, dan positif dengan $+(5 \mathrm{mg} / \mathrm{dL})$ sebanyak 1 orang.

Tabel 2 memperlihatkan distribusi nilai keton berdasarkan usia kehamilan. Pada minggu ke- 4 terdapat 1 orang yang negatif, minggu ke- 8 terdapat 4 orang negatif dan 2 orang positif dengan kadar $+1(5 \mathrm{mg} / \mathrm{dL})$ dan +++ $(50 \mathrm{mg} / \mathrm{dL})$, sedangkan pada minggu ke- 12 terdapat 2 orang negatif dan 1 orang positif dengan kadar $+1(5 \mathrm{mg} / \mathrm{dL})$.

\section{BAHASAN}

Hiperemesis gravidarum adalah mual dan muntah berlebihan selama masa kehamilan. Seringnya muntah dan berkurangnya nafsu makan menyebabkan penderita tidak mendapatkan asupan makanan dengan baik dan kadar glukosa di dalam darah menjadi rendah, akhirnya tubuh akan menggunakan lemak sebagai bahan pengganti karbohidrat dalam proses pembentukan energi yang menyebabkan peningkatan produksi keton yang dapat terdeteksi di darah maupun urin. ${ }^{8}$ 
Tabel 1. Distribusi kadar keton berdasarkan kelompok usia

\begin{tabular}{cccccc}
\hline $\begin{array}{c}\text { Usia } \\
\text { (tahun) }\end{array}$ & Negatif & $\begin{array}{c}+ \\
(\mathbf{5 m g} / \mathbf{d L})\end{array}$ & $\begin{array}{c}+++ \\
\mathbf{( 1 5} \mathbf{~ m g / d L})\end{array}$ & $\begin{array}{c}++++ \\
(\mathbf{5 0} \mathbf{~ m g} / \mathbf{d l})\end{array}$ & $\begin{array}{c}++++ \\
\mathbf{( 1 5 0} \mathbf{~ m g} / \mathbf{d L})\end{array}$ \\
\hline $18-23$ & 4 & 1 & 0 & 1 & 0 \\
$24-29$ & 3 & 1 & 0 & 0 & 0 \\
Total & 7 & 2 & 0 & 1 & 0 \\
\hline
\end{tabular}

Tabel 2. Distribusi nilai keton berdasarkan usia kehamilan

\begin{tabular}{cccccc}
\hline $\begin{array}{c}\text { Usia } \\
\text { (minggu ke-) }\end{array}$ & Negatif & $\begin{array}{c}+ \\
(\mathbf{5 m g} / \mathbf{d L})\end{array}$ & $\begin{array}{c}++ \\
(\mathbf{1 5} \mathbf{~} \mathbf{~ g} / \mathbf{d L})\end{array}$ & $\begin{array}{c}+++ \\
(\mathbf{5 0} \mathbf{~ m g} / \mathbf{d l})\end{array}$ & $\begin{array}{c}++++ \\
(\mathbf{1 5 0} \mathbf{~ m g} / \mathbf{d L})\end{array}$ \\
\hline ke-4 & 1 & 0 & 0 & 0 & 0 \\
ke-8 & 4 & 1 & 0 & 1 & 0 \\
ke-12 & 2 & 1 & 0 & 0 & 0 \\
Total & 7 & 2 & 0 & 1 & 0 \\
\hline
\end{tabular}

Keberadaan keton dalam urin bukan merupakan hal normal. Keton hanya akan dibentuk saat terjadi defisiensi karbohidrat dan tidak dibentuknya energi dari glukosa. Keton kemudian akan beredar dalam darah dan diedarkan ke seluruh tubuh melalui pembuluh darah menuju organ-organ penting seperti otak dan otot dimana keton dibutuhkan sebagai energi pengganti. ${ }^{9}$

Karena keton bersifat asam, tubuh akan menghasilkan basa sebagai buffer untuk mempertahankan keseimbangan asam-basa tubuh. Bila tubuh terus-menerus menggunakan keton sebagai energi, suatu saat cadangan basa tubuh akan habis dan hal ini akan menimbulkan keadaan darurat yaitu ketoasidosis yang dapat mengancam nyawa. Hal ini menjadi dasar untuk melakukan pemeriksaan keton pada wanita hamil, terlebih lagi yang mengalami hiperemesis gravidarum. ${ }^{9}$

Keadaan seperti ketoasidosis diabetik, kelaparan, hamil, ketoasidosis alkoholik, diet tinggi protein rendah karbohidrat, muntah, diare, dan hipoglikemi merupakan keadaan-keadaan yang dapat memicu produksi keton dalam tubuh. ${ }^{9}$ Badan keton tidak hanya diukur sebagai bagian dari urinalisis lengkap, tetapi dilakukan untuk menglasifikasi atau mengobati beberapa populasi pasien seperti pasien yang masuk rumah sakit dengan keadaan darurat (terutama pasien pediatri), juvenile onset diabetes, atau pasien dengan toksemia pada kehamilan. Setelah terapi insulin dan cairan pada diabetes dengan hiperglikemi dan ketosis, $\beta$-hidroksibutirat jaringan diubah kembali menjadi asetoasetat yang menyebabkan peningkatan sementara dari eksresi asetoasetat di urin meskipun keadaan klinisnya membaik. ${ }^{10}$

\section{SIMPULAN}

Berdasarkan hasil penelitian ini dapat disimpulkan bahwa sebagian wanita hamil trimester 1 dengan hiperemesis gravidarum $(30 \%)$ mengalami ketonuria.

\section{SARAN}

Disarankan perlunya penelitian lanjut dengan peningkatan jumlah subyek penelitian untuk menghindari terjadinya bias dalam penelitian serta diperlukan acuan pustaka tambahan yang menunjang penelitian selanjutnya.

\section{DAFTAR PUSTAKA}

1. Dorland WAN. Kamus Kedokteran Dorland (29th ed). Hartanto et al, alih bahasa. Jakarta: ECG, 2002.

2. Prawirohardjo S. Perubahan anatoni dan fisiologi ibu hamil. In: Bari SA et al, editors. Ilmu Kebidanan (4th ed). Jakarta: Yayasan Bina Pustaka, 2009; p. 175-86.

3. Cunningham, Leveno, Hauth, Bloom, Rouse, Spong. Fisiologi pada perempuan hamil. In: Setia $\mathrm{R}$ et al, editors. Obstetri Williams (23 rd ed). Jakarta: 
EGC, 2014; p. 128-30.

4. Nuraif AH, Kusuma H. Aplikasi Asuhan Keperawatan Berdasarkan Diagnosa Medis \& NANDA (North American Nursing Diagnosis Association) NICNOC. Jakarta: Media Hardi, 2012.

5. Departemen Kesehatan RI. Hiperemesis Gravidarum. Jakarta, 2013; p. 12.

6. Gunawan K, Manengkei PSK, Ocviyanti D. Diagnosis dan tata laksana hiperemesis gravidarum. Indon Med Assoc. 2011: 61;458-64.

7. Comstock JP, Garber AJ. Ketonuria. Metode Klinis: Sejarah, Fisika, dan Labora- torium Pemeriksaan (3rd ed). New York: MacMilan, 2011.

8. Varney H. Buku Ajar Asuhan Kebidanan (4th ed). Jakarta: EGC, 2007; p. 608.

9. Devkota BP. Ketones. October 30th 2015. [cited 2016 Dec 14]. Available from:http://emedicine.medscape.com/ar ticle/2087982-overview\#showall.

10. European Confederation of Laboratory Medicine. European Urinalysis Guidelines. Scand J Lab Invest. 2000;60:196. 